\title{
Dental Clinic Interior Model as an Alternative to Child Anxiety
}

\author{
Muhamad Rohim ${ }^{1}$, Bedjo Santoso ${ }^{2}$, Ari Suwondo ${ }^{3}$, Lanny Sunarjo ${ }^{4}$ \\ Semarang Health Polytecnic, Semarang, Indonesia \\ Semarang Health Polytecnic, Semarang, Indonesia \\ Semarang Health Polytecnic, Semarang, Indonesia \\ Semarang Health Polytecnic, Semarang, Indonesia \\ Email: mochboiem19@gmail.com
}

\section{ARTICLE INFO}

Date Received: 12

November 2020

Revision Date : 20

December 2020

Date Received : 03

January 2021

\section{Keywords:}

Clinic Interior Model;

Child Anxiety

\begin{abstract}
Children experience higher anxiety than adults this is due to emotional differences and mental development according to age, one of the efforts to overcome anxiety is to provide dental health education using methods, media and models of dental clinic rooms tailored to the needs of the child. In general, dental clinic rooms have white and creepy shades. The interior model of the dental clinic is made specifically to address the anxiety of the child at the time of childcare. Research Objective: produce an interior model of dental clinics as an alternative to child anxiety management. Research and Development (R\&D) method, and model test using quasi-experimental non randomized control group pre-test and post-test design. Sampling techniques with purposive sampling, the study subjects were children who performed treatment at the dental clinic, divided into 2 groups of 20 children each, group 1. intervention of dental clinic interior models with wall wallpapers and acoustic videostimulions and 2. Media posters and dental health counseling as a control group. Data tested with Wilcoxon and Mann-whitney tests. The result shows "Dental Clinic Interior Model"effective as an alternative to child anxiety management is shown with a $p$-value value of 0.036. There is a difference in the effectiveness of the "dental clinic interior model" with counseling and poster for child anxiety management is shown with a $p$-value of 0.102 . The test results are not paired with a p-value of 0.036 . Thus, "Dental Clinic Interior Model" effectively lowers children's anxiety levels
\end{abstract}

Coresponden Author:

Email: mochboiem19@gmail.com Article with open access under license

\section{INTRODUCTION}

Anxiety in dental care is a major obstacle for the child when receiving dental care. Children have limited communication skills and are less able to express their fears and anxieties. Their behavior is a reflection of their inability to cope with anxiety.(Sutela, Rahaswanti, \& Weta, 2019), (Gupta, Marya, Bhatia, \& Dahiya, 2014) The feeling of anxiety experienced by the child is an instinct that arises according to the development process, the difference in age is different as well as the emotional development shown by the child. These feelings arise through observations in the surrounding environment as well as strange and unpleasant objects and the child tries to avoid them in an effort to protect themselves from harm, this reason that can be made by the child not to do dental care.(Agustiyaningsih \& Kustiningsih, 2017).

The prevalence of anxiety in dental care worldwide reaches $6-15 \%$, with variations in different countries and in different sample populations. (Simon R, 2014) Based on the survey by Al Sarheed, $16 \%$ of schoolchildren have feelings of anxiety and even fear to go to the dental clinic.(SP, 2014),(Bunga'Allo, Lampus, \& Gunawan, 2016) The results of the study in Indonesia $22 \%$ expressed fear and anxiety when doing dental treatment bhkan before going to the clinic was already anxious.5 These feelings can be found in children in various dental care units such as in dental clinics, health centers and in hospitals.(Bunga'Allo et al., 2016).

Research conducted by Kartono and Sartono suggests that there are three factors that influence anxiety: the sound of bur $81.46 \%$, sitting in the dental chair $50.72 \%$, the needle $39.13 \%$, the dental instrument $39.13 \%$ and the negative experience story about dental care from others $33.33 \%$. (Arlette Suzy Setiawan, Zidnia, \& Sasmita, 2010) However, anxiety will decrease with age. (Shim, Kim, Jeon, \& An, 2015).

The health of the child's teeth and mouth, can be attempted by parents by inviting the child to check to the dental clinic but in practice, the children are 
less cooperative in the treatment process so dental health workers have difficulty to handle the child..These difficulties are not only related to the treatment process, but there are also emotional differences between the child and the health workers. Fear and anxiety are emotions often shown by the child during dental treatment.(Mittal \& Sharma, 2012)

The success of dental and oral health services in children is influenced by good service facilities, so as to reduce children's anxiety while in dental care and can increase children's trust in the services provided by dental health workers.(Tanudjaya, 2014)

General Purpose: Produce the interior model of the dental clinic as an Alternative to Child Anxiety.

Based on the background above, researchers intend to design a child-friendly dental clinic interior model tailored to the child's age characteristics, using perception stages for control with therapeutic communication, attention focus using wall wallpaper media and mind therapy with acoustic stimulation videos. as an attempt to decrease anxiety levels at the time of childcare treatment at the dental clinic.

\section{METHOD}

The research method used is Research and Development $(R \& D)$. This research aims to produce innovative dental clinic models. The R\&D method is a research method used to produce new products or improve existing products and can be answered the results(Sugiyono, 2017), (Sukmadinata, 2012)

Research and Development (R\&D) research is a mix-method research. The research mix-method is a method of combining qualitative and quantitative approaches. Research and development procedures include 5 main steps including: 1) information collection, 2) product or model design, 3) expert validity and revision, 4) trial of product or model and 5) product or model results.(Fatahilah, Rahayu, \& Soekardi, 2017) Sampling technique using purposive sampling with 2 intervention groups and control group of 20 children each.

A child's anxiety can be measured by questionnaires, scales or degrees of varying levels of validity and reliability. Questionnaires to be used are Modifed dental axienty scale and Abeer Dental Children Axienty Scale.(Al-Namankany, Ashley, \& Petrie, 2012), (Humphris, Morrison, \& Lindsay, 1995) This questionnaire is a measurement of anxiety based on the appearance of reactions in individuals who check into dental clinics.

A child's anxiety can be measured by questionnaires, scales or degrees of varying levels of validity and reliability. Questionnaires to be used are Modifed dental axienty scale and Abeer Dental Children Axienty Scale.(Al-Namankany et al., 2012), (Humphris et al., 1995). This questionnaire is a measurement of anxiety based on the appearance of reactions in individuals who check into dental clinics. Each item in observation is given 5 levels of score as follows:

\section{RESULT AND DISCUSSION}

\section{A. Information Collection}

Dental and Oral Health Services are conducted by providing Communication, Information and Education (KIE) to parents and/or other family members in the form of: counseling/counseling about the growth phase of the firstborn teeth and the circumstances that accompany the process of teething and abnormalities/diseases that often occur in children and teaching how to maintain the health of the child's oral cavity before teething until the teeth of the series grow complete. The involvement of parents and/or other family members must be actively carried out in order to establish healthy behaviors and independence of toddlers and preschool-aged children optimally in the maintenance and improvement of their dental and oral health. The method is a persuasive and communicative direct approach method, therapeutic communication, indirect communication with $2 \mathrm{D}$ and 3D media With the method of play, puppet play, in the gift of giving care, can be by watching videos from visual media. Media used are: Praga tool that can be held, poster media, or 3D media that can be seen by the child, audio visuals containing images that are of interest to the child, Media posters, images, animated videos, puppet plays, so that the child can distract him.

\section{B. Design model}

The results of information collection are used in the design of the interior model of the dental clinic as an alternative to child anxiety management.

\section{Expert Validation}

Table 1 Expert Validation Statistics Test

\begin{tabular}{cccc}
\hline & \multicolumn{3}{c}{ Expert Validity } \\
\cline { 2 - 3 } & $\mathrm{N}$ & $\mathrm{f}(\%)$ & $P$-Value \\
\cline { 2 - 3 } Relevant & 10 & 100 & \\
\hline Irrelavant & 0 & 0 & 0.01 \\
\hline
\end{tabular}

*intraclass correlation coefficient

The result of expert validation shows that the $p$ value $=0.001$, which means that

\begin{tabular}{|c|c|c|c|c|c|c|c|c|}
\hline \multirow[b]{2}{*}{$\begin{array}{l}\mathrm{Gr} \\
\text { ou } \\
\mathrm{p}\end{array}$} & \multicolumn{5}{|c|}{ Paired t-test } & \multicolumn{3}{|c|}{ Unpaired t-test } \\
\hline & & $\mathbf{n}$ & Mean & SD & $\begin{array}{l}\text { p- } \\
\text { value }\end{array}$ & $\begin{array}{l}\Delta \\
\text { Me } \\
\text { an }\end{array}$ & $\begin{array}{l}\text { Su } \\
\mathrm{m} \\
\text { of } \\
\mathrm{Ra} \\
\mathrm{nk}\end{array}$ & $\begin{array}{l}\text { p- } \\
\text { value }\end{array}$ \\
\hline $\begin{array}{l}\text { Int } \\
\text { erv }\end{array}$ & $\begin{array}{l}\mathrm{Pr} \\
\mathrm{e}\end{array}$ & $\begin{array}{l}2 \\
0\end{array}$ & 2.20 & 0.410 & 0.020 & $\begin{array}{l}17 . \\
80\end{array}$ & $\begin{array}{l}35 \\
6.0 \\
\end{array}$ & 0,036 \\
\hline
\end{tabular}




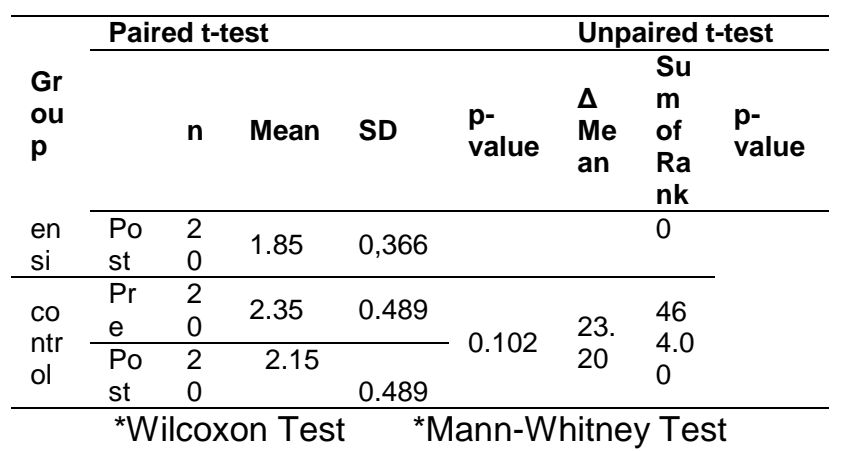

Statistical test results of data pairing child anxiety intervention group $p$-value value is 0.020 $(p<0.05)$ meaning the Dental Clinic Interior model effectively lowers child anxiety.

The results showed that there were differences between the intervention group and the control group after being treated. The results of the data test did not show that the $p$-value between intervention and control groups was $0.036(p<0.05)$ meaning that there were differences in the Interior model of ran dental clinics more effective at lowering anxiety compared to dental clinics that were counseled and given posters.

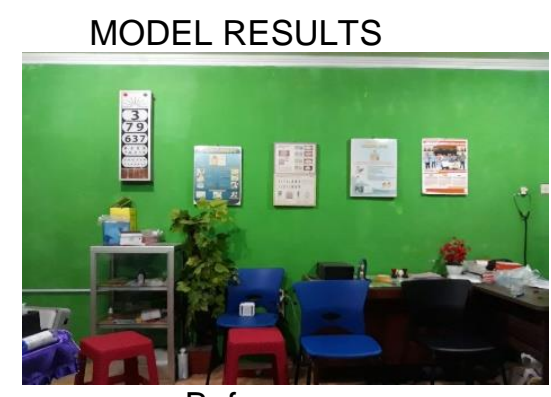

Before

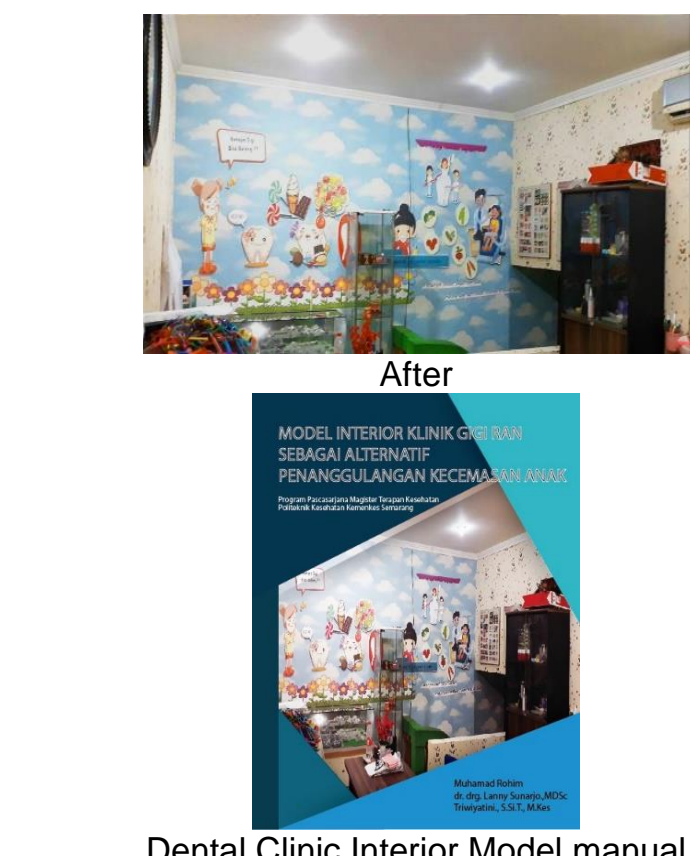
DISCUSSION
Efforts to lower children's anxiety levels when dental care is needed is a special dental clinic interior model for the child and one of the models in tackling anxiety in the child's dental and oral care through innovation and development of the interior model of a child-friendly dental clinic.

The process of validation of experts is important in the development of useful models in health promotion activities.(Heri Setiawan, Adi, \& Ulfah, 2017) The equipment required in development research is the experts (ecpertist) who will be used as determining the theory and validity of the model.

Based on the results of the study there were some children who did not control back to the clinic in the intervention group of the number of children who did not control as many as 3 children with moderate anxiety criteria while in the control group as many as 2 children, with moderate and severe anxiety criteria. This is influenced by lack of knowledge, negative parental attitudes, time constraints, moving places of residence, quality of health care, no family support.(Sihotang \& Rahma, 2017)

The age of 5-12 years is a sensitive period or sensitive period in the child, i.e. a period where a certain function needs to be stimulated, directed so as not to be inhibited by development. This period to perform the first basis in developing physical, cognitive, language, social, emotional, self-concept, discipline, self-reliance and others.(Indraswari, 2012)

The decrease in anxiety caused by the proper therapeutic communication process between health workers and child patients means a lot to the success in childcare measures so that the information conveyed is appropriate and does not cause anxiety.(Slamet \& Sarwinanti, 2014)

The decrease in anxiety caused because before the child is taken treatment is given the introduction of the room first, visualize the waiting room with in the video of acoustic stimulation and in ruangna action is carried out the introduction of an attractive room for the child with a media wallpaper wall that has colors and images that can educate the child to recognize and understand the mis health of the teeth and how to maintain dental health with help by dental health workers. So that the child's attitude can be formed by obtaining information, providing feedback and actions after being given the information. (Siwiendrayanti, Pawenang, \& Indarjo, 2017) Therapy to overcome children's anxiety can be done with non pharmacological therapy, with special vision, sound and comfort in the room environment in the dental clinic can affect the anxiety of the child at the time of dental treatment.(Savitri, 2018)

The success of the dental clinic interior model is also seen from the decrease in child anxiety, because the child is introduced to an attractive and 
child-friendly interior room model, this is supported by previous research stating that Modelling wall wallpaper and acoustic stimulation videos is a technique performed by utilizing the child's vision to introduce a friendly room in the same way of experience, thus reducing the anxiety of the child high.22, 23.

\section{CONCLUSION}

Dental Clinic Interior Model is feasible as an alternative model to lower the level of child ness, This is evidenced by the results of effectiveness test showing that the value of $p$-value $=0.036$

\section{REFERENSI}

Agustiyaningsih, Sulis, \& Kustiningsih, Kustiningsih. (2017). Hubungan Stress Hospitalisasi dengan Perubahan Pola Tidur Pasien Anak Usia Prasekolah di RSKIA PKU Muhammadiyah Kotagede Yogyakarta. Universitas' Aisyiyah Yogyakarta.

Al-Namankany, Abeer, Ashley, Paul, \& Petrie, Aviva. (2012). The development of a dental anxiety scale with a cognitive component for children and adolescents. Pediatric Dentistry, 34(7), 219E-224E.

Bunga'Allo, Chinda B., Lampus, Benecditus S., \& Gunawan, Paulina N. (2016). Hubungan perasaan takut anak terhadap perawatan gigi dengan kebersihan gigi dan mulut di RSGM Unsrat Manado. E-GiGi, 4(2).

Fatahilah, Adika, Rahayu, Setya, \& Soekardi, Soekardi. (2017). Model Latihan dengan Teknik Relaksasi Berbantuan Aromaterapi dan Musik Instrumental untuk Menurunkan Kecemasan Atlet. Journal of Physical Education and Sports, 6(3), 211-217.

Gupta, Anil, Marya, Charu M., Bhatia, Hind Pal, \& Dahiya, Vandana. (2014). Behaviour management of an anxious child. Stomatologija, 16(1), 3-6.

Humphris, Gerry M., Morrison, T., \& Lindsay, S. J. E. (1995). The Modified Dental Anxiety Scale: validation and United Kingdom norms. Community Dental Health.

Indraswari, Lolita. (2012). Peningkatan Perkembangan Motorik Halus Anak Usia Dini Melalaui Kegiatan Mozaik Di Taman KanakKanak Pembina Agam. Jurnal Pesona PAUD, 1(1), 1-13.

Mittal, Rakesh, \& Sharma, Meenakshi. (2012). Assessment of psychological effects of dental treatment on children. Contemporary Clinical Dentistry, 3(Suppl1), S2.

Savitri, Mutia Arum. (2018). Hubungan Desain Interior Klinik Gigi Terhadap Kecemasan Pasien Sebelum Perawatan Gigi Dan Mulut. Fakultas Kedokteran Gigi Unissula.

Setiawan, Arlette Suzy, Zidnia, Hilnia, \& Sasmita, Inne Suherna. (2010). Mozart effect on dental anxiety in 6-12 year old children. Dent J, 43(1), 17-20.

Setiawan, Heri, Adi, Sapto, \& Ulfah, Nurnaningsih Herya. (2017). Pengembangan multimedia interaktif berbasis autoplay sebagai media promosi kesehatan tentang kesehatan gigi dan mulut pada siswa kelas V SDN Percobaan 02 Kota Malang. Preventia: The Indonesian Journal of Public Health, 2(2), 93-103.

Shim, Youn Soo, Kim, Ah Hyeon, Jeon, Eun Young, \& An, So Youn. (2015). Dental fear \& anxiety and dental pain in children and adolescents; a systemic review. Journal of Dental Anesthesia and Pain Medicine, 15(2), 53.

Sihotang, Hetty Maria, \& Rahma, Nursiti. (2017). Faktor Penyebab Penurunan Kunjungan Bayi di Posyandu Puskesmas Langsat Pekanbaru Tahun 2016. Jurnal Endurance: Kajian IImiah Problema Kesehatan, 2(2), 168-177.

Siwiendrayanti, Arum, Pawenang, Eram Tunggul, \& Indarjo, Sofwan. (2017). Environmental Control and Behavior Increasing In Filariasis Elimination Through The Implementation Of "Mandiri" Pocket Book. The 4th International Conference On Physical Education, Sport And Health (Ismina) and Workshop: Enhancing Sport, Physical Activity, and Health Promotion For A Better Quality Of Life, 961.

Slamet, Sri Puji Rahayu, \& Sarwinanti, Sarwinanti. (2014). Pengaruh Komunikasi Terapeutik terhadap Tingkat Kecemasan pada Keluarga Pasien yang Dirawat di Ruang PICU RSUP Dr Sardjito Yogyakarta. STIKES'Aisyiyah Yogyakarta.

SP, Andi. (2014). Pola Perilaku Anak Terhadap Perawatan Gigi dan Mulut [Skripsi]. Makassar: Fakultas Kedokteran Gigi Universitas Hasanuddin.

Sugiyono. (2017). Statistika Untuk Penelitian. Bandung: Alfabeta.

Sukmadinata, Nana Syaodih. (2012). Metode Penelitian Pendidikan, PT Remaja 
Rosdakarya. Bandung.

Sutela, I. Gede Marantika Yogananda, Rahaswanti, L. W. Ayu, \& Weta, I. Wayan. (2019). Hubungan early childhood caries (ECC) dengan status gizi anak umur 3-5 tahun di wilayah kerja Puskesmas Mengwi III Badung. Bali Dental Journal, 3(2), 74-78.
Tanudjaya, Pratama Kesuma. (2014). Pengaruh kualitas pelayanan klinik gigi terhadap kepuasan dan kepercayaan pasien sehingga meningkatkan keinginan untuk berobat kembali. Jurnal Manajemen Dan Pemasaran Jasa, 7(1), 39-60. 